\title{
Идентичность, социокультурный потенциал, ценностные ориентации и оценка перспектив цивилизационного будущего у тувинских и русских студентов Сибири
}

\author{
Юрий В. Попков \\ Институт философии и права Сибирского отделения Российской академии наук, \\ Российская Федерация
}

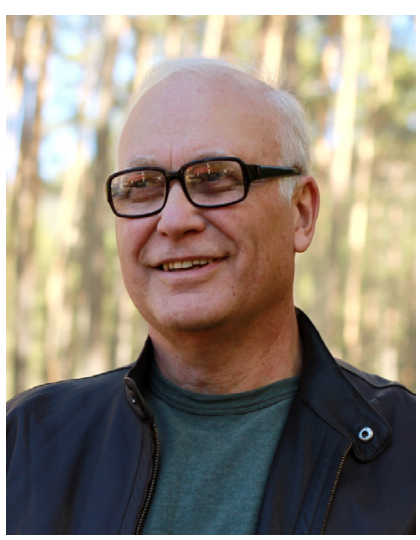

В статье обобщаются результаты опроса осени 2020 г. тувинских и русских студентов аграрных вузов пяти крупнейших городов Сибири (Иркутска, Красноярска, Новосибирска, Омска, Барнаула). Автор сравнивает степени соответствия их социокультурного потенциала базисным основаниям духовно-экологической стратегии развития общества. Данная цивилизационная стратегия обосновывается как альтернатива техногенно-потребительской модели социального устройства, которая доминирует в современном мире и многими экспертами оценивается как кризисная. В компаративистском ключе решается ряд задач.

Несмотря на нынешнюю ситуацию с коронавирусом, для большинства молодых людей свойственно чувство уверенности и спокойствия. Тувинцы являются социально более устойчивыми и менее требовательными к внешним обстоятельствам. Определенную тревогу у них вызывают перспективы собственной жизни. Выявлен запрос на социальную справедливость в обществе и благополучие основной массы населения. Нерешенность этих и других социальных проблем выступает одним из факторов невысокого уровня общенациональной идентичности у респондентов. У тувинцев в больщей степени, чем у русских, выражена этническая и сибирская идентичности, но одинаково высокой у двух групп является глобальная идентичность.

В среде молодых людей доминируют ценности, которые тесно связаны с традиционной культурой. В своем преимущественном большинстве (с небольшим перевесом у тувинщев) они считают наиболее важными для себя наличие хорошей семьи, здоровья, образования, дружеских отношений с родственниками, коллегами, соседями, а также экологически благоприятной природной среды. Малопривлекательными являются для них участие в политике, статусные амбиции, жизнь за границей, а также жизнь в сельской местности.

Многие студенты считают, что доминирующая в настоящее время модель техногенно-потребительской цивилизации находится в состоянии кризиса и абсолютное их большинство поддерживают идею перехода к альтернативной духовно-экологической стратегии развития. Для социокультурного потенциала молодых людей в целом свойственны качественные характеристики, которые могут составлять необходимые предпосылки для реализации данной модели. Среди тувинцев больше, чем среди русских, уверенных в возможности обозначенной перспективы развития, что в значительной степени связано с особенностями их менталитета как носителей традиций буддизма и кочевничества.

Ключевые слова: циивилизационная цеенность; молодежь России; Сибирь; тувинцы; русские; студент; социология молодежи; идентичность молодежи; представление о будущем

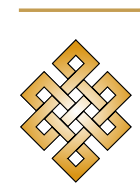

Для цитирования:

Попков Ю. В. Идентичность, социокультурный потенциал, ценностные ориентации и оценка перспектив цивилизационного будущего у тувинских и русских студентов Сибири // Новые исследования Тувы. 2021, № 1. C. 217-227. DOI: https://www.doi.org/10.25178/nit.2021.1.12

Попков Юрий Владимирович - доктор философских наук, профессор, главный научный сотрудник отдела социальных и правовых исследований Института философии и права Сибирского отделения Российской академии наук. Адрес: 630090, Россия, г. Новосибирск, ул. Николаева, д. 8. Тел.: +7 (383) 330-22-40. Эл. адрес: yuripopkov54@mail.ru

POPKOV, Yuri Vladimirovich, Doctor of Philosophy, Professor; Chief Researcher, Department of Social and Legal Studies, Institute of Philosophy and Law, Siberian Branch, Russian Academy of Sciences. Postal address: 8 Nikolaev St., 630090 Novosibirsk, Russian Federation. Tel.: +7 (383) 330-22-40. E-mail: yuripopkov54@mail.ru 


\title{
Identity, socio-cultural potential, value orientations and assessment of the prospects of the civilizational future among Tuvan and Russian students in Siberia
}

\author{
Yuri V. Popkov \\ Institute of Philosophy and Law, Siberian Branch of the Russian Academy of Sciences, Russian Federation
}

\begin{abstract}
The article summarizes the outcomes of a survey conducted in autumn 2020 among Tuvan and Russian students of agricultural universities in the five largest Siberian cities (Irkutsk, Krasnoyarsk, Novosibirsk, Omsk, and Barnaul). The author compares how much their socio-cultural potential matches the basis of the spiritual and ecological strategy of society development. This civilizational strategy is introduced as an alternative to the technogenic-consumer model of social order, which dominates in the modern world and is assessed by many experts as one of a crisis type. A range of issues is considered in the article in a comparative way.

Despite the current situation with COVID-19 pandemic, most young people tend to feel calm and confident. Tuvans are socially more stable and less demanding of external conditions. They are particularly concerned about the prospects of their own lives. There is a demand for social justice and the well-being of the population. These and other unresolved social problems are one of the factors explaining the respondents' low level of national identity. Tuvans have more conspicuous ethnic and Siberian identities than Russians, but the global identity is equally high in both groups.

Values intricately connected to traditional culture dominate among young people. In their majority (with a small superiority among the Tuvans) they consider most important to have a good family, health, education, friendly relations with relatives, colleagues, neighbors, as well as a good ecological environment. Involvement in politics, career ambitions, life abroad, as well as life in the countryside do not appeal to them.

Many students believe that the currently dominant model of technogenic-consumer civilization is in a state of crisis and most of them support the idea of moving on to an alternative spiritual and ecological development strategy.

The socio-cultural potential of young people in general is characterized by qualitative characteristics that can provide the prerequisites for implementing this model. Tuvans students - more frequently than Russians - are confident that this transition is possible, which is largely due to the influence of Buddhist and nomadic traditions.
\end{abstract}

Keywords: civilizational value; Russian youth; Siberia; Tuvans; Russians; student; youth sociology; youth identity; view of the future

For citation:

Popkov Yu. V. Identity, socio-cultural potential, value orientations and assessment of the prospects of the civilizational future among Tuvan and Russian students in Siberia. New Research of Tuva, 2021, no. 1, pp. 217-227. (In Russ.). DOI: https://www.doi.org/10.25178/nit.2021.1.12

\section{Введение}

Тувинская молодежь вместе с молодежью других национальностей и других регионов страны принадлежит к такому отряду населения, которому предстоит выступать главной движущей силой грядущих цивилизационных преобразований. Поэтому изучение ее мнения относительно будущего своего общества - тувинского, сибирского, российского - важная тема для тувиноведения. Однако, поскольку это будущее не может рассматриваться автономно от будущего всей страны, и даже всего мира, нам важно понимать не только то, что полагает тувинская молодежь, но и сравнивать ее мнение с мнением молодежи из других российских регионов.

Цель статьи состоит в сравнительном анализе социального самочувствия, идентичности, социокультурного потенциала и ценностных ориентаций тувинской и русской студенческой молодежи Сибири, а также оценке ее представлений об актуальной перспективной модели будущего развития общества. В качестве такой перспективы принимается цивилизационная модель, разработанная барнаульскими коллегами и названная ими духовно-экологической (или ноосферной) (Иванов, Фотиева, Шишин, 2014). Суть ее состоит в целенаправленном преобразовании разных сфер жизни в фокусе приоритета духовных и экологических ценностей. Одновременно она рассматривается ими, с чем мы также солидарны, как альтернативная доминирующей ныне техногенно-потребительской цивилизации.

С учетом актуализации именно такой модели цивилизационного развития группа исследователей под руководством А. В. Иванова при участии автора статьи в сентябре 2020 г. провела эмпирическое социологическое исследование, цель которого состояла в том, чтобы выявить отношение людей 
к техногенно-потребительской и духовно-экологической моделям цивилизационного развития. Для массового опроса определена студенческая молодежь как отряд населения, которому предстоит выступать главной движущей силой будущих преобразований. Именно потенциал молодежи и система ее ценностей будут во многом определять характер этих преобразований. Акцент сделан на сибирском регионе как стратегически важном для России, а также с учетом убеждения организаторов исследования в том, что от Сибири и благополучия ее жителей в значительной мере зависит будущее всей страны (Иванов, 2019).

В качестве целевой группы для опроса взяты студенты ведущих сельскохозяйственных вузов Восточной и Западной Сибири - из городов Иркутска, Красноярска, Новосибирска, Омска, Барнаула. Акцент на аграрных вузах определялся двумя обстоятельствами: 1) в них в большей степени, чем в других вузах, представлена не только городская, но и сельская молодежь; 2) в последнее время обозначилась, а в период пандемии обнаружила себя со всей очевидностью тенденция массового движения городских жителей за пределы городского пространства; возникшую ситуацию исследователи характеризуют как эпидемический вариант «кризисной дезурбанизации» и рассматривают как начало постурбанизационной стадии развития (Покровский, Макшанчикова, Никишин, 2020: 54). Поэтому учет мнения молодых людей, ценностный мир которых сформировался вне городских условий, представляется весьма перспективным.

Выборочная совокупность составила 585 студентов 2-3 курсов очной формы обучения, из них $47 \%$ - мужчины, $53 \%$ - женщины; $42 \%$ респондентов до поступления в вуз жили в селе, $56 \%$ - в городе ( $2 \%$ не ответили на этот вопрос). Выборка целенаправленная, методом отбора являлся «сплошной массив» (опрашивались все, кто присутствовал на занятиях). Преобладающая часть всех опрошенных (501 чел.) являются русскими. Второй по численности этнической группой оказались тувинцы студенты, которые обучаются в сибирских вузах, -22 чел., остальные - единичные представители многих других народов.

Небольшое количество тувинских студентов не дает основания говорить о полноценной выборке для этой группы. Однако анализ результатов опроса позволил обнаружить своеобразие оценок тувинцев по целому ряду вопросов в сравнении с остальными респондентами. Это говорит о том, что примененная авторская методика ${ }^{1}$ оказалась способной уловить определенные различия ответов респондентов даже на небольшом массиве. Поэтому анализ социологических данных применительно к тувинцам вполне допустим: его можно рассматривать как пилотажное, предварительное исследование, которое дает возможность получить значимую информацию в рамках заданной темы с возможной перспективой ее рассмотрения в будущем на более солидном массиве. При этом важно иметь в виду особенность группы опрошенных тувинцев: она представляет молодых людей родом из Тувы, которые несколько лет живут и учатся в других регионах Сибири, то есть в той или иной степени адаптировались к условиям существования за пределами своей исторической родины. Поэтому к ней вполне применим вывод: «Источниками ее ценностных ориентиров могут быть как традиционные социокультурные институты, так и новые» (Бадмаев и др., 2020: 37).

Главный фокус дальнейшего анализа сконцентрируем на характеристике результатов опроса применительно к тувинским студентам в сравнении с ответами русских респондентов с акцентом на тех моментах, по которым наблюдаются отличия в оценках.

\section{Молодежь и будущее}

Прежде чем обратиться к анализу результатов нашего эмпирического исследования, обратим внимание на два важных момента.

Во-первых, вопрос об особенностях культуры и системы ценностей тувинцев является достаточно разработанным в литературе (см., например: Ламажаа, 2011, 2018). Широкий спектр отдельных проблем в последнее десятилетие активно обсуждается в журнале «Новые исследования Тувы», в том числе в номерах, посвященных специальным конкретным темам: «Менталитет тувинцев в компаративистской перспективе» (2017, № $\left.3^{2}\right)$; «Проблемы экономической культуры и деловой этики тувинцев в XXI веке» (2018, № $2^{3}$ ); «Взаимосвязь этнокультуры, экономики, этнодемографических

\footnotetext{
${ }^{1}$ Инструментарий и содержательные вопросы социологического исследования разработаны А. В. Ивановым и Ю. В. Попковым.

${ }^{2}$ https://nit.tuva.asia/nit/issue/view/35

${ }^{3}$ https://nit.tuva.asia/nit/issue/view/38
} 
процессов в пространственном развитии Тувы» (2019, № $3^{1}$ ); «Тува и Ойратский мир: исторические связи, этнокультурные контакты, вопросы идентичности» (2019, № $4^{2}$ ). Особо выделим обобщающую статью Ч. К. Ламажаа об исследовании менталитета тувинцев (Ламажаа, 2017).

Во-вторых, изучение молодежи России является достаточно популярной темой. Из существующих работ отметим объемную монографию М. К. Горшкова и Ф. Э. Шереги, в которой по итогам многолетних исследований в разных регионах России дана характеристика данной социальной группы по широкой палитре параметров (Горшков, Шереги, 2020). Среди множества обсуждаемых вопросов в издании есть глава, специально посвященная ценностным ориентациям молодого поколения. Здесь нет акцента на обществе будущего в заданном аспекте. В то же время авторы делают важный вывод о значимости в среде молодежи традиционных ценностей: «Однако большинство все-таки осознают актуальность традиционных ценностей для общества» (там же: 178).

Две другие монографии непосредственно связаны с рассмотрением проблем молодежи в контексте образа будущего (Образ будущего ... , 2016; Молодежь индустриальных ... , 2018). В них затрагиваются в том числе вопросы, важные для анализа некоторых аспектов нашей темы, например, о поисках «новой духовности» (Образ будущего ..., 2016: 32), о сходстве с нашими результатами данных по итогам анализа значимости ценностей семьи, здоровья, дружеских отношений и др. (там же: 64-67), о рисках и угрозах, которые существуют на пути реализации потенциала молодежи (Молодежь индустриальных ... 2018). Однако не рассматривается проблема, которая для нас является главной - молодежь и цивилизационное будущее России.

Это же касается исследований тувинской молодежи. Первое комплексное исследование социального положения молодого поколения Тувы было предпринято коллективом тувинских историков и новосибирских этносоциологов в советский период (Молодежь Тувы. ..., 1988). В постсоветский период изучение отдельных проблем молодежи было продолжено небольшими исследовательскими группами (см. обзор: Ламажаа, 2015). Из последних работ следует выделить сравнительное социологическое исследование студенческой молодежи трех традиционно буддийских регионов Россия (Тувы, Бурятии и Калмыкии) в контексте религиозной тематики (Бадмаев и др., 2020). Но в этих работах также не ставилась задача анализа ценностей и социокультурного потенциала молодежи в связи с цивилизационным будущим.

\section{Социальное самочувствие}

Напомним, что наш опрос проходил в сентябре 2020 г., то есть уже во время пандемии коронавируса. Она в существенной степени осложнила жизнь людей, но при этом не заняла полностью все их жизненное пространство. Поэтому один из первых вопросов касался степени общей удовлетворенности респондентов: «Все мы сейчас переживаем непростые времена. Но жизнь многогранна и не сводится только к сложностям. Насколько Вы довольны своей жизнью в целом?» Среди русских чуть более половины опрошенных студентов (53\%) в целом довольны своей жизнью, среди тувинцев таких несколько больше (68\%) и нет ни одного, кто был бы ей не доволен. На вопрос непосредственно об их общем самочувствии доля позитивных ответов (уверенность и спокойствие) оказалась еще выше и опять с превышением данного показателя у тувинцев - 86\% (против 66\% у русских).

В ходе подготовки исследования исходно предполагалась гипотеза, что социальное самочувствие во многом связано со сложной текущей ситуацией. Поэтому при формулировке предполагаемых ответов на вопрос анкеты о том, что больше всего беспокоит респондента в настоящее время, первым был поставлен пункт «Проблемы, связанные с коронавирусом». И он оказался значимым, однако далеко не для большинства студентов. Русские обеспокоены этим меньше, чем тувинцы. Более весомыми причинами беспокойства являются для русских личные проблемы, которые для тувинцев менее значимы.

Одновременно тувинцы меньше русских встревожены перспективами развития России, а также Сибири (на обеспокоенность перспективами развития Сибири обратил внимание каждый десятый русский, среди тувинцев таковых в три раза меньше). Но самое удивительное состоит в том, что каждого четвертого из тувинских студентов в настоящий момент ничего не беспокоит (среди русских таковых в шесть раз меньше). Возможно, данное обстоятельство связано с особенностями ментали-

${ }^{1}$ https://nit.tuva.asia/nit/issue/view/43

${ }^{2}$ https://nit.tuva.asia/nit/issue/view/44 
тета тувинцев как носителей традиций буддизма и кочевничества, что проявляется в «философском» отношении к жизни, невысоких от нее ожиданиях и нетребовательности к внешним обстоятельствам. Высокий уровень приверженности современной тувинской молодежи буддизму четко фиксируют специальные исследования (Бадмаев и др., 2020).

Можно сделать вывод, что факторами беспокойства в жизни студентов, оказывающими влияние на их социальное самочувствие, являются не только острая текущая ситуация эпидемии коронавируса и перспективы их собственной жизни, но и социально значимые проблемы, касающиеся будущего России и Сибири. Последнее у тувинцев выражено в меньшей степени, чем у русских, но они обладают большей социальной устойчивостью перед трудностями в силу особенностей их менталитета.

\section{Идентичность}

С учетом особенностей респондентов, в качестве которых определены студенты аграрных вузов, в ходе опроса среди первых были заданы вопросы о том, где каждый из них проживал до поступления в вуз - в селе или городе и кем он себя считает - городским жителем или сельским. И нам удалось выявить социальную проблему, которая является общей для многих городов. Суть ее в том, что в последние годы многие, часто вынужденно переселившись из села в город, не стали истинными горожанами, но в село возвращаться не хотят, поскольку там до сих пор нет особых перспектив, особенно для молодежи.

Хотя две трети опрошенных нами тувинцев непосредственно до поступления в вуз жили в городе, около половины из них считают себя сельскими жителями, а еще почти каждый третий не мог себя четко идентифицировать по этому параметру. В то же время лишь только каждый четвертый из тувинских респондентов отметил ценность для себя жизни в селе. Для большинства из них, как и для русских студентов, более привлекательным является в настоящее время городской образ жизни.

Как представляется, дело тут не только в обстоятельствах субъективного плана, касающихся личных предпочтений молодых людей, но и в реальных проблемах развития села, современной сельской жизни и ее перспективах. Известно, что за постсоветский период в России исчезли или почти исчезли десятки тысяч деревень. И основания для слома этой тенденции в виде кардинального изменения государственной политики в отношении села до сих пор не просматриваются.

Таким образом, можно констатировать серьезную проблему, которая по своим истокам и проявлениям имеет комплексный характер: даже из обучающихся в специализированных сельскохозяйственных вузах немногих привлекает современная жизнь в селе, большинство студентов, скорее всего, планируют в перспективе остаться жить в городе.

Что касается других видов идентичности, то представление о них дают данные табл. 1.

Табл. 1. Степень важности разных видов идентичности, \% от числа опрошенных в этнических группах.

Table 1. The importance of various identities, \% of respondents within each ethnic group

\begin{tabular}{|c|c|c|c|c|c|}
\hline \multirow{2}{*}{$N^{o} N^{o}$} & \multirow{2}{*}{ Виды идентичности } & \multicolumn{2}{|c|}{ Важно } & \multicolumn{2}{|c|}{ Не важно } \\
\hline & & Тувинцы & Русские & Тувинцы & Русские \\
\hline 1 & Ощущать себя россиянином & 64 & 54 & 27 & 32 \\
\hline 2 & $\begin{array}{l}\text { Ощущать себя представителем своей } \\
\text { национальности }\end{array}$ & 86 & 54 & 14 & 32 \\
\hline 3 & Ощущать себя сибиряком & 73 & 50 & 18 & 35 \\
\hline 4 & $\begin{array}{l}\text { Ощущать себя жителем своего края } \\
\text { (республики, области) }\end{array}$ & 73 & 56 & 14 & 32 \\
\hline 5 & Ощущать себя гражданином мира & 86 & 63 & 9 & 20 \\
\hline 6 & Жить среди людей своей национальности & 41 & 28 & 41 & 57 \\
\hline
\end{tabular}

Прим.: респонденты должны были дать один ответ по каждой строке. 
Прежде всего обращает на себя внимание то обстоятельство, что все выделенные виды идентичности по степени важности для человека у тувинцев являются более выраженными, чем у русских. Но если у последних гражданская, этническая, сибирская и региональная идентичности характеризуются практически одинаковыми и относительно невысокими значениями (50\% и чуть выше), то у тувинцев (кроме того, что они более высокие) здесь проявляется явная дифференциация. Меньшие показатели имеет гражданская (общенациональная) идентичность. Аналогичные данные среди тувинцев фиксируют и другие авторы (Бадмаев и др., 2020: 39). Результаты наших прежних исследований также подтверждают такие выводы (Мадюкова, Персидская, Попков, 2017: 75-77).

С учетом официальной установки на формирование общенациональной (гражданской) идентичности как безусловного приоритета государственной публичной политики выявленные нами представления молодых людей могут показаться отклонением от российского мейнстрима. Но с этим нельзя согласиться по нескольким причинам.

Во-первых, высокий уровень этнической идентичности в нашем случае отражает особенности развития локальных сообществ сибирского макрорегиона, в котором сильны этнокультурные традиции.

Во-вторых, мы исходим из убеждения, подтвержденного результатами многолетних исследований, о неправомерности противопоставления общенациональной и этнической идентичности, которые на самом деле являются совместимыми, непротиворечивыми (Дробижева, 2019: 234; Попков, Тюгашев, 2020: 237-241).

B-третьих, низкий уровень общенациональной идентичности во многом связан с критическим отношением к власти, с неудовлетворенностью населения, в том числе молодежи, состоянием реальной государственной политики. Как показало наше исследование, в большей степени неудовлетворенными от деятельности федеральной власти являются наиболее актуальные запросы молодежи на достойное благосостояние народа, обеспечение социальной справедливости, законности и порядка. Эту проблему мы, как и другие исследователи, фиксировали и ранее (Дробижева, 2016: 340-341; Попков, Тюгашев, 2020: 243-246). Негативную динамику критического отношения молодежи к власти в последние годы 3. В. Сикевич и Н. Г. Скворцов отмечают по результатам массовых опросов в Санкт-Петербурге (Сикевич, Скворцов, 2020: 277, 288). При этом они разделяют (совершенно справедливо) три разных понятия: «Родина» - «государство» - «власть», которые часто не дифференцируются, в том числе при разговоре об общенациональной (гражданской) идентичности.

B-четвертых, именно низкая эффективность политики федеральных властей, проявляющаяся в отсутствии в обществе должной социальной справедливости и слабой выраженности в этой политике интересов основной массы населения, является одним из главных факторов невысокого уровня общенациональной идентичности. В этих условиях актуализируется региональная и этническая идентичности, выступающие своеобразными компенсаторами тех защитных социальных механизмов, которые люди не могут найти в рамках официальной государственной политики.

Возвращаясь к анализу результатов нашего опроса, заметим, что сибирская идентичность более выражена у тувинцев. При ответе на дополнительный прямой вопрос «Считаете ли Вы себя сибиряком» лишь один из тувинцев затруднился с ответом, все остальные высказались положительно. Среди русских доля таковых немного меньше. Одновременно тувинцы, по сравнению с русскими, в большей степени обнаруживают и этноцентристские установки (жить среди людей своей национальности) (табл. 1). Это проявляется, в частности, в том известном факте, что тувинские студенты, находясь на учебе вне своей республики, поддерживают тесные контакты друг с другом в рамках своих землячеств.

Схожесть позиций, хотя и с различающимися количественными показателями, проявляется в отношении глобальной идентичности (важность ощущать себя гражданином мира): у тувинцев и русских она является доминирующей в ряду других видов идентичности (соответственно 86 и 63\%, у тувинцев сопоставима с этнической идентичностью) (табл. 1). Столь высокий уровень выявленной глобальной идентичности можно отнести к числу неожиданных результатов опроса. Одно из объяснений, которое лежит на поверхности - это включенность современных молодых людей в глобальную информационную сеть что является для них важной составляющей текущей повседневности. Другие объяснения и самого данного факта, и его последствий для ценностного сознания и реального поведения людей требуют специального исследования. 


\section{Социокультурный потенциал и цеенностные ориентации}

Можно говорить о весьма благополучной ситуации в отношении той части социокультурного потенциала молодежи, которая касается ее отношения к традициям и культуре своего и других народов. Они рассматриваются как имеющие высокую ценность (табл. 2). При этом молодые люди четко высказываются и за то, чтобы также их дети знали культуру и традиции своего народа. Как и в предыдущей серии вопросов, позитивные установки являются более выраженными у тувинцев.

Табл. 2. Степень важности культурных традиций, в \% от числа опрошенных в этнических группах.

Table 2. The importance of cultural traditions, \% of respondents within each ethnic group.

\begin{tabular}{|c|c|c|c|c|c|}
\hline \multirow{2}{*}{$N^{o} N^{o}$} & \multirow{2}{*}{ Культурные традиции } & \multicolumn{2}{|c|}{ Важно } & \multicolumn{2}{|c|}{ Не важно } \\
\hline & & Тувинцы & Русские & Тувинцы & Русские \\
\hline 1 & $\begin{array}{l}\text { Знать культуру своего народа, своей } \\
\text { национальности }\end{array}$ & 95 & 73 & 5 & 14 \\
\hline 2 & $\begin{array}{l}\text { Чтобы мои дети знали культуру моего } \\
\text { народа }\end{array}$ & 95 & 71 & 5 & 15 \\
\hline 3 & Соблюдать традиции своего народа & 91 & 51 & 9 & 27 \\
\hline 4 & $\begin{array}{l}\text { Соблюдать религиозные обычаи своего } \\
\text { народа }\end{array}$ & 73 & 33 & 23 & 41 \\
\hline 5 & $\begin{array}{l}\text { Уважать традиции и обычаи других } \\
\text { народов }\end{array}$ & 86 & 78 & 14 & 11 \\
\hline
\end{tabular}

Примечательно, что абсолютное большинство студентов обеих национальностей настроено на уважительное отношение к традициям и обычаям других народов. Эта установка характеризуется даже более солидными количественными показателями, чем ориентация на соблюдение религиозных традиций своего собственного народа. Но опять обратим внимание на то, что тувинцы по сравнению с русскими здесь выглядят гораздо более весомо. Данный факт лишний раз подтверждает особое качество тувинцев, касающееся религиозной составляющей их культуры - традиционность.

Что касается других жизненно важных ценностей, то и здесь в среде молодежи доминируют ценности, которые тесно связаны с традиционной культурой. Молодые люди в своем преимущественном большинстве (с небольшим перевесом у тувинцев) считают наиболее важными для себя наличие хорошей семьи, здоровья, образования, дружеских отношений с родственниками, коллегами, соседями, а также экологически благоприятную природную среду. Малопривлекательными являются для них участие в политике, статусные амбиции, жизнь за границей, а также, как отмечалось, жизнь в сельской местности. Примерно для половины опрошенных не является принципиально важным состоять в зарегистрированном браке, причем среди тувинцев таковых немного меньше.

Результаты нашего исследования по большому счету совпадают с общими выводами, которые делают М. К. Горшков и Ф. Э. Шереги по итогам социологического опроса, проведенного под их руководством по единой методике во всех типах поселений 21 региона России в период 2009-2019 гг.: «Нынешняя российская молодежь в целом не индивидуалистична, не агрессивна, не стремится обладать властью, нечестолюбива» (Горшков, Шереги, 2020: 181).

В этой связи отметим следующее. Фундаментальной основой системы ценностей человека является ориентация по основанию: индивидуализм - коллективизм (либерализм - коммунитаризм). Для выяснения позиции студентов по данному основанию во время опроса им был задан вопрос, что важнее: интересы человека или интересы народа. Отвечая на него, русские респонденты разделились примерно поровну, среди тувинцев оказалось больше тех, кто приоритет отдает интересам народа.

Признание значимости традиционных ценностей, которые являются коллективистскими по своей природе, выступает важным индикатором наличия в социокультурном потенциале молодежи тех качественных характеристик, которые могут составлять необходимые предпосылки для реализации перспективной духовно-экологической стратегии развития. 
Говоря в этой связи о тувинцах, следует акцентировать их коллективистскую черту, сформировавшуюся в рамках традиционной хозяйственной деятельности и повседневной жизнедеятельности. Она была зафиксирована в том числе во время отмеченного выше первого комплексного исследования проблем социального развития Тувы в виде наличия разнообразных видов взаимопомощи, прежде всего среди родственных групп (Очерки социального ... 1983: 79). Это отмечают также авторы недавно проведенного (в 2019 г.) под руководством 3. Т. Голенковой социологического исследования в Туве. Взаимопомощь существует не только в межличностных отношениях, но и на уровне домохозяйств. Такую стратегию они охарактеризовали «сетью взаимопомощи домохозяйств» (Социально-стратификационные процессы ... , 2020: 88). Мне самому доводилось неоднократно наблюдать сохранение традиции взаимопомощи тувинцев практически в каждый свой приезд в Туву. Этот пример подтверждает тот факт, что элементы традиционной культуры могут сохранять свою устойчивость на протяжении длительного времени.

\section{Молодежь о глобальных трендах цивилизационного развития}

Как было отмечено во вводной части, существующую в настоящее время мировую цивилизацию можно назвать техногенно-потребительской. Она базируется на частной собственности, либеральнорыночных ценностях с приматом конкуренции как определяющего типа социальных взаимодействий. Ее основополагающими признаками являются индивидуализм, социальная и экономическая конкуренция, групповой и национальный эгоизм, чрезмерная эксплуатация природы, установка на ее безусловное покорение (Иванов, Фотиева, Шишин, 2014: 119-123). Специалисты на Западе ее до сих пор называют капиталистической и ассоциируют с буржуазной эпохой. Распространенной является точка зрения о кризисе, который переживает эта цивилизация в настоящее время.

Студентам предлагалось высказать свое мнение относительно этой точки зрения. $60 \%$ русских дали положительный ответ. Мнение тувинцев разделилось практически поровну между теми, кто считает, что техногенно-потребительская цивилизация находится в состоянии кризиса, и теми, кто затруднился ответить на этот вопрос (видимо, он не часто обсуждается в студенческой среде). Очень немногие из опрошенных не поддержали обозначенную позицию о кризисе данной цивилизации.

Более определенным является мнение тувинцев при ответе на вопрос «Считаете ли Вы, что для современного мира нужна альтернативная, духовно-экологическая цивилизация, основанная на принципах сохранения окружающей среды, примата культуры, науки и образования над политикой и экономикой, на идеях сотрудничества и взаимопомощи между людьми, культурами и народами?» Чуть более 4/5 всех опрошенных тувинцев поддержали эту позицию. Среди русских доля таковых немного меньше.

В вопросе о возможности перехода общества к духовно-экологической цивилизации ответы дифференцировались в основном между двумя ответами: «вполне возможно» (так считают около $2 / 5$ тувинцев и $1 / 4$ русских) и «возможно, но не скоро» (соответственно чуть более $1 / 4$ и почти $1 / 2$ ). Лишь единицы считают, что в этом нет необходимости. В целом среди тувинцев больше, чем среди русских, уверенных в возможности обозначенной перспективы развития (без конкретизации того, когда это может произойти), но также больше затруднившихся дать определенный ответ.

Что касается возможного личного участия опрошенных в актуальных перспективных преобразованиях, то в обеих группах преобладает ориентация на абстрактно-пассивные формы такого участия в виде честного исполнения профессиональных обязанностей и воспитания своих детей в русле духовно-экологических ценностей. Но тувинцы проявили большую готовность к инициированию и реализации соответствующих практических проектов в своем регионе.

Среди тех качеств сибиряков, которые могут составлять необходимые предпосылки для трансформации современной модели развития в более гуманное и справедливое общество, базирующееся на приоритете духовных и экологических ценностей, молодые люди, с несколько более высокими показателями у тувинцев, отдают предпочтение таким существующим здесь качествам, как склонность к взаимопомощи и взаимовыручке, мужество, а также вера в собственные силы.

\section{Заключение}

Рассмотренная выше постановка вопроса о двух типах цивилизационного развития не относится к числу активно присутствующих в российском политическом, научном и образовательном дис- 
курсах. Но если в рамках социально-философского обсуждения данная тема в литературе все-таки присутствует, то на эмпирическом уровне проведенное под руководством А. В. Иванова при участии автора исследование, насколько нам известно, осуществлено впервые.

Обобщая результаты представленного анализа, можно сделать заключение, что социокультурный потенциал студенческой молодежи, характер их ценностных ориентаций в целом соответствуют базовым принципам духовно-экологической стратегии развития. Тувинцы проявляют несколько большую выраженность этого потенциала, большую уверенность в такой перспективе цивилизационных изменений, как и большую практическую готовность что-то реально сделать для этого.

Как представляется, фундаментальное основание такого положения вещей лежит в глубинных возможностях традиционной культуры, многие элементы которой не просто сохраняются в адаптированном к нынешним условиям виде, но и оказываются востребованными современностью.

В этой связи хочется обратить внимание на одну идею, которую еще четверть века назад отстаивал Ю. М. Бородай, говоря о принципиальном отличии индустриальной цивилизации (системы) от постиндустриальной. Первая является техноцентричной, вторая - культурноцентричной (Бородай, 1996: 392). Здесь даже применительно к собственно производственному процессу морально-духовные качества человека оказываются определяющими. «Материальные предпосылки развития, при всей их важности, отступают на второй план» (там же: 393). Именно умение задействовать потенциал традиционных культур позволил ныне известным как «восточноазиатские тигры» странам сделать прорыв в будущее не только в экономике, но и других сферах жизни.

Можно ли использовать имеющийся позитивный социокультурный потенциал молодежи Сибири для перспективных цивилизационных трансформаций? Очевидно - да. Но такое возможно при комплексе условий, среди которых обозначим три выявленные в ходе исследования и требующие осмысления и преодоления проблемные ситуации.

Первая касается самих молодых людей. Для ряда студентов рассматриваемая проблематика оказалась практически незнакомой до момента нашего опроса. Это можно объяснить двумя основными обстоятельствами: во-первых, отсутствием этой проблематики в вузовских учебных программах; вовторых, равнодушием части студентов к соответствующим вопросам, инфантилизмом, а также тем, что их вполне устраивает существующее положение вещей. Подтверждением данного вывода могут служить ответы, которые дали некоторые студенты на вопрос о том, что можно было бы сделать для формирования более гуманного и справедливого общества. Они, хотя и единичные, являются достаточно красноречивыми: «Ничего», «А зачем оно мне надо?»

Второй системной проблемой является нежелание абсолютного большинства студентов связать свою перспективу с селом. Ценность сельской жизни является и у русских, и у тувинцев самой низкой в ряду всех других выделенных ценностей. И это, обратим внимание, касается не молодежи вообще, а целевой группы студентов сельскохозяйственных вузов, которые изначально призваны готовить специалистов для села. Изменить положение дел в этой области невозможно в том числе без кардинального изменения государственной политики в отношении села.

Третья проблемная ситуация касается того очевидного факта, что само государство не актуализировало и не предложило обоснованную перспективную модель цивилизационного развития России, хотя в последнее время эта тема дискутируется в философских кругах и начала подниматься на разных уровнях управления. Образ будущего, к которому должны стремится и власть, и само общество - для населения в целом, для молодежи в частности, остается неопределенным.

\section{СПИСОК ЛИТЕРАТУРЫ}

Бадмаев, В. Н., Уланов, М. С., Ламажаа, Ч. К., Бичелдей, У. П., Антонов, В. И., Очирова, О. А. (2020) Россия и буддийский мир глазами молодежи Тувы, Бурятии и Калмыкии (по материалам социологического опроса) // Новые исследования Тувы. № 1. С. 35-49. DOI: https://doi.org/10.25178/nit.2020.1.3

Бородай, Ю. М. (1996) Эротика - смерть - табу: трагедия человеческого сознания. М. : Гнозис, Русское феноменологическое общество. 416 с.

Горшков, М. К., Шереги, Ф.Э. (2020) Молодежь России в зеркале социологии. К итогам многолетних исследований. М. : ФНИСЦ РАН. 688 с. DOI: https://doi.org/10.19181/monogr.978-5-89697-325-6.2020

Дробижева, Л. М. (2016) Заключение // Межнациональное согласие как ресурс консолидации российского общества / отв. ред. Л. М. Дробижева. М. : Институт социологии РАН. 400 с. С. 333-353. 
Дробижева, Л. М. (2019) Политика интеграции полиэтнического российского общества в доктринальных документах, политологическом дискурсе и массовом сознании // Общественные науки и современность. № 4. С. 134-146. DOI: https://doi.org/10.31857/S086904990005821-5

Иванов, А. В. (2019) Освоение и развитие Сибири как третий российский стратегический геопроект // Вестник Омского университета. Т. 24. № 3. C. 84-95. DOI: https://doi.org/10.25513/1812-3996.2019.24(3).84-95

Иванов, А. В., Фотиева, И. В., Шишин, М. Ю. (2014) На путях к новой цивилизации (очерки духовно-экологического мировоззрения). Барнаул : Изд-во АлтГТУ. 219 с.

Ламажаа, Ч. К. (2011) Тува между прошлым и будущим. 2-е изд. СПб. : Алетейя. 368 с.

Ламажаa, Ч. К. (2015) Социология молодежи Тувы // Знание. Понимание. Умение. № 3. С. 340-348. DOI: https:// www.doi.org/10.17805/zpu.2015.3.30

Ламажаа, Ч. К. (2017) Исследования менталитета тувинцев и тенденция субъективизации гуманитарного знания // Новые исследования Тувы. № 3. С. 18-48. DOI: https://www.doi.org/10.25178/nit.2017.3.2

Ламажаа, Ч. К. (2018) Национальный характер тувинцев. М. ; СПб. : Нестор-История. 240 с.

Мадюкова, С. А., Персидская, О. А., Попков, Ю. В. (2017) Общенациональная и этническая идентичность молодежи этнических групп республик Сибири в сравнительной перспективе // Знание. Понимание. Умение. № 3. C. 69-83. DOI: $10.17805 / \mathrm{zpu} .2017 .3 .6$

Молодежь индустриальных регионов России: образ социального будущего и инновационный потенциал (2018) / Я. В. Дидковская, Л. Н. Банникова, Л. Н. Боронина, Ю. Р. Вишневский, К. М. Ольховиков, Д. В. Трынов. Екатеринбург : Изд-во Урал. ун-та. 215 с.

Молодежь Тувы. Социальный портрет (1988) / Анайбан 3. В., Золототрубов В. С., Кочергин В. А. и др. Новосибирск : Наука. Сиб. отд-ние. 194 с.

Образ будущего в оценках нового поколения россиян (2016) / В. В. Гаврилюк, Л. Л. Мехришвили, Н. И. Скок [и др.]. Тюмень : ТИУ. 166 с.

Очерки социального развития Тувинской АССР (1983) / В. И. Бойко, В. Н. Белошапкина, Г. Ч. Ширшин и др. Новосибирск : Наука. 264 с.

Покровский, Н. Е., Макшанчикова, А. Ю., Никишин, Е. А. (2020) Обратная миграция в условиях пандемического кризиса: внегородские пространства России как ресурс адаптации // Социологические исследования. № 12. C. 54-64. DOI: https://doi.org/10.31857/S013216250010726-1

Попков, Ю. В., Тюгашев, Е. А. (2020) Этнокультурный неотрадиционализм и идентичность в современных социокультурных трансформациях. Новосибирск : Изд-во НГТУ. 256 с.

Сикевич, 3. В., Скворцов, Н. Г. (2020) Соотношение национальной и этнической идентичности молодежи (на примере Санкт-Петербурга) // Вестник Российского университета дружбы народов. Серия: Социология. Т. 20 . № 2. C. 277-291. DOI: 10.22363/2313-2272-2020-20-2-277-291

Социально-стратификационные процессы в Республике Тыва (2020) / 3. Т. Голенкова и др.; отв. ред. 3. Т. Голенкова, Ю. В. Голиусова, П. Е. Сушко; ФНИСЦ РАН. М. ; Кызыл : ФНИСЦ РАН. 128 с. DOI: https://doi.org/10.19181/ monogr.978-5-89697-332-4.2020

Дата поступления: 12.01.2021 2.

\section{REFERENCES}

Badmaev, V. N., Ulanov, M. S., Lamazhaa, Ch. K., Bicheldei, U. P., Antonov, V. I. and Ochirova, O. A. (2020) Rossiia i buddiiskii mir glazami molodezhi Tuvy, Buriatii i Kalmykii (po materialam sotsiologicheskogo oprosa) [Russia and the Buddhist world through the eyes of the youth in Tuva, Buryatia and Kalmykia: a sociological survey and its outcomes]. New Research of Tuva, no. 1, pp. 35-49. (In Russ.). DOI: www.doi.org/10.25178/nit.2020.1.3

Borodai, Yu. M. (1996) Erotika - smert' - tabu: tragediia chelovecheskogo soznaniia [Erotics - Death - Taboo: The Tragedy of Human Consciousness]. Moscow, Gnozis, Russkoe fenomenologicheskoe obshchestvo. 416 p. (In Russ.).

Gorshkov, M. K. and Sheregi, F. E. (2020) Molodezh' Rossii v zerkale sotsiologii. K itogam mnogoletnikh issledovanii [The Youth of Russia in the Mirror of Sociology. The outcomes of a long-term study]. Moscow, FNISTs RAN. 688 p. (In Russ.). DOI: www.doi.org/10.19181/monogr.978-5-89697-325-6.2020

Drobizheva, L. M. (2016) Zakliuchenie [Conclusion]. In: Mezhnatsional'noe soglasie kak resurs konsolidatsii rossiiskogo obshchestva [Interethnic consent as a resource for the consolidation of Russian society] / ed. by L. M. Drobizheva. Moscow, Institut sotsiologii RAN. 400 p. Pp. 333-353. (In Russ.). 
Drobizheva, L. M. (2019) Politika integratsii polietnicheskogo rossiiskogo obshchestva v doktrinal'nykh dokumentakh, politologicheskom diskurse i massovom soznanii [The policy of integration of the multi-ethnic Russian society: doctrinal documents, political discourse and mass consciousness]. Obshchestvennye nauki i sovremennost', no. 4, pp. 134-146. (In Russ.). DOI: www.doi.org/10.31857/S086904990005821-5

Ivanov, A. V. (2019) Osvoenie i razvitie Sibiri kak tretii rossiiskii strategicheskii geoproekt [The exploration and development of Siberia as the third Russian strategic geoproject]. Vestnik Omskogo universiteta, vol. 24, no. 3, pp. 84-95. (In Russ.). DOI: www.doi.org/10.25513/1812-3996.2019.24(3).84-95

Ivanov, A. V., Fotieva, I. V. and Shishin, M. Yu. (2014) Na putiakh k novoi tsivilizatsii (ocherki dukhovno-ekologicheskogo mirovozzreniia) [On the road to a new civilization: Essays on the spiritual and ecological worldview)]. Barnaul, Izd-vo AltGTU. 219 p. (In Russ.).

Lamazhaa, Ch. K. (2011) Tuva mezhdu proshlym i budushchim [Tuva between the past and future]. $2^{\text {nd }}$ ed. St. Petersburg, Aleteya. 368 p. (In Russ.).

Lamazhaa, Ch. K. (2015) Sotsiologiia molodezhi Tuvy [Sociology of youth in Tuva]. Znanie. Ponimanie. Umenie, no. 3, pp. 340-348. (In Russ.). DOI: www.doi.org/10.17805/zpu.2015.3.30

Lamazhaa, Ch. K. (2017) Issledovaniia mentaliteta tuvintsev i tendentsiia sub"ektivizatsii gumanitarnogo znaniia [Studies of mindset of Tuvans and the subjectivity trend in academic knowledge]. New Research of Tuva, no. 3, pp. 18-48. DOI: https://www.doi.org/10.25178/nit.2017.3.2

Lamazhaa, Ch. K. (2018) Natsional'nyi kharakter tuvintsev [National character of Tuvans]. Moscow, St. Petersburg, Nestor-Istoriia. 240 p. (In Russ.)

Madiukova, S. A., Persidskaia, O. A. and Popkov, Yu. V. (2017) Obshchenatsional'naia i etnicheskaia identichnost' molodezhi etnicheskikh grupp respublik Sibiri v sravnitel'noi perspektive [Nationwide and ethnic identity of young people of ethnic groups living in Siberian republics in a comparative perspective]. Znanie. Ponimanie. Umenie, no. 3, pp. 69-83. DOI: www.doi.org/10.17805/zpu.2017.3.6

Molodezh' industrial'nykh regionov Rossii: obraz sotsial'nogo budushchego i innovatsionnyi potentsial [Youth in industrial regions of Russia: The vision of the social future and innovative potential] (2018) / Ya. V. Didkovskaia, L. N. Bannikova, L. N. Boronina, Yu. R. Vishnevskii, K. M. Ol'khovikov and D. V. Trynov. Ekaterinburg, Izd-vo Ural. un-ta. 215 p.

Molodezh' Tuvy. Sotsial'nyi portret [The Youth of Tuva: A social portrait] (1988) / ed. by Yu. L. Aranchyn. Novosibirsk, Nauka. 194 p. (In Russ.).

Obraz budushchego $v$ otsenkakh novogo pokoleniia rossiian [The image of the future in the assessments of the new generation of Russians] (2016) / V. V. Gavriliuk, L. L. Mekhrishvili, N. I. Skok et al. Tiumen', TIU. 166 p.

Ocherki sotsial'nogo razvitiia Tuvinskoi ASSR [Essays on social development of the Tuvan ASSR] (1983) / ed. by Yu. L. Aranchyn. Novosibirsk, Nauka. 262 p. (In Russ.).

Pokrovskii, N. E., Makshanchikova, A. Yu. and Nikishin, E. A. (2020) Obratnaia migratsiia v usloviiakh pandemicheskogo krizisa: vnegorodskie prostranstva Rossii kak resurs adaptatsii [Reverse migration in the pandemic crisis: Russia's outof-town spaces as an adaptation resource]. Sotsiologicheskie issledovaniia, no. 12, pp. 54-64. DOI: www.doi.org/10.31857/ S013216250010726-1

Popkov, Yu. V. and Tiugashev, E. A. (2020) Etnokul'turnyi neotraditsionalizm i identichnost' v sovremennykh sotsiokul'turnykh transformatsiiakh [Ethno-cultural neotraditionalism and identity in modern socio-cultural transformations]. Novosibirsk, Izd-vo NGTU. 256 p.

Sikevich, Z. V. and Skvortsov, N. G. (2020) Sootnoshenie natsional'noi i etnicheskoi identichnosti molodezhi (na primere Sankt-Peterburga) [The correlation between national and ethnic identities it Saint Petersburg youth)]. RUDN Journal of Sociology, vol. 20, no. 2, pp. 277-291. DOI: www.doi.org/10.22363/2313-2272-2020-20-2-277-291

Sotsial'no-stratifikatsionnye protsessy v Respublike Tyva [Socio-stratification processes in the Republic of Tuva] (2020) / Z. T. Golenkova et al., ed. by Z. T. Golenkova, Yu. V. Goliusova and P. E. Sushko. Moscow, Kyzyl, FNISTs RAN. 128 p. DOI: https://doi.org/10.19181/monogr.978-5-89697-332-4.2020

Submission date: 12.01.2021. 